\title{
Oesophageal foreign body: the importance of imaging in multiple coin ingestion
}

\author{
Brendan Wright, ${ }^{1}$ Peter Leyden ${ }^{2}$
}

'Department of ENT, Health and Social Care Services in Northern Ireland, Belfast, UK ${ }^{2}$ Department of ENT, Southern Health and Social Care Trust, Portadown, UK

\section{Correspondence to Brendan Wright} bwright01@qub.ac.uk

Accepted 23 October 2016

\section{(1) CrossMark}

To cite: Wright $B$, Leyden $P$. BMJ Case Rep Published online: [please include Day Month Year] doi:10.1136/ bcr-2016-218040

\section{DESCRIPTION}

A woman aged 61 years presented to a district general hospital with a 5-day history of dysphagia, regurgitation of all liquids and solids and lower sternal pain. She had a background of metastatic lung cancer with brain metastases and had previously received chemotherapy and radiotherapy. She was intermittently confused and had no recollection of ingesting a foreign body. On examination, her oral cavity, oropharynx and neck were unremarkable. Plain chest X-ray revealed a midline opaque foreign body at the level of the clavicular heads in the shape of a single coin (figure 1). A lateral soft tissue neck X-ray revealed, on close inspection, the presence of two foreign bodies and these appeared to be two coins lying on top of one another at the approximate level of T3 (figure 2).

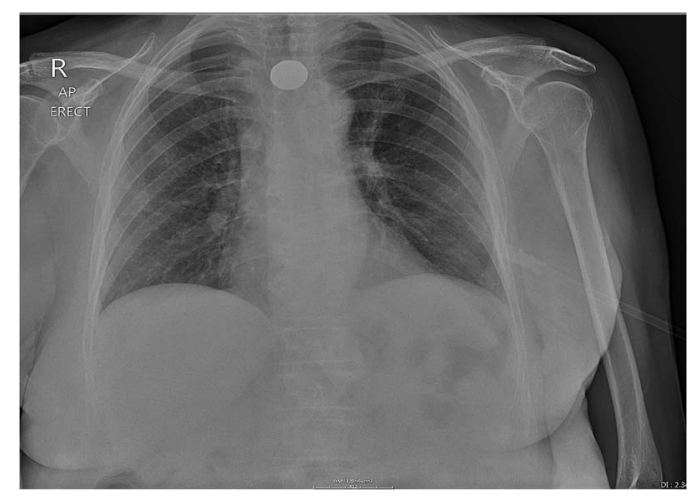

Figure 1 Erect chest $\mathrm{X}$-ray showing an opaque foreign body in the shape of a single coin at the level of the clavicular heads.

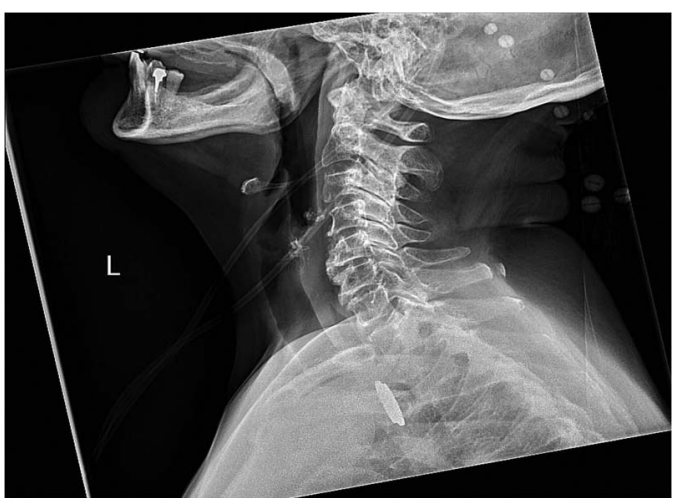

Figure 2 Lateral soft tissue neck X-ray showing two coins at the level of T3 in the upper oesophagus with an air bubble more proximally.
The patient was fasted and taken to theatre for a rigid oesophagoscopy. Intraoperatively, two 20 pence coins were removed from the upper oesophagus. The region of foreign body impaction was slightly ulcerated and so the patient was started on oral proton pump inhibitors.

Studies have shown that a lateral film is not always obtained in cases of coin ingestion. ${ }^{1}$ Also, some prevertebral radio-opaque foreign bodies will only be visible on a lateral film. ${ }^{2}$ Anteroposterior and lateral X-rays allowed for this case to be managed more effectively and safely. Knowing the exact number of coins allowed the surgeon to avoid more risky distal endoscopy at and beyond the area of oesophageal ulceration in a patient with significant comorbidity.

\section{Learning points}

- It is good practice to obtain anteroposterior (AP) and lateral X-rays in cases of oesophageal foreign body to allow for more accurate characterisation of the foreign body and better surgical planning; especially in cases of coin ingestion, where it is possible to have perfect radiological alignment of several coins on an AP view.

- Without a lateral film, it would be possible to miss a second or multiple coins on plain imaging, as demonstrated in this case.

- AP and lateral X-rays in cases of multiple oesophageal coin impactions in high-risk patients allow for a safer endoscopic approach to avoid more distal exploration beyond ulcerated areas in the oesophagus.

Contributors BW and PL contributed to the design, writing and revision of this article.

Competing interests None declared.

Patient consent Obtained.

Provenance and peer review Not commissioned; externally peer reviewed.

\section{REFERENCES}

1 Balasubramaniam SK, Bray D, Black MI, et al. A review of the current management of impacted foreign bodies in the oesophagus in adults. Eur Arch Otorhinolaryngol 2008;265:951-6.

2 Pinto A, Muzj C, Gagliardi N, et al. Role of imaging in the assessment of impacted foreign bodies in the hypopharynx and cervical oesophagus. Semin Ultrasound CT MR 2012;33:463-70. 
Copyright 2016 BMJ Publishing Group. All rights reserved. For permission to reuse any of this content visit http://group.bmj.com/group/rights-licensing/permissions.

BMJ Case Report Fellows may re-use this article for personal use and teaching without any further permission.

Become a Fellow of BMJ Case Reports today and you can:

- Submit as many cases as you like

- Enjoy fast sympathetic peer review and rapid publication of accepted articles

- Access all the published articles

- Re-use any of the published material for personal use and teaching without further permission

For information on Institutional Fellowships contact consortiasales@bmjgroup.com

Visit casereports.bmj.com for more articles like this and to become a Fellow 